\title{
The Role of Forests in Mitigating Climate Change - a Case Study for Europe
}

\author{
Borbála GÁLOS $^{\mathrm{a}^{*}}$ - Andreas HÄNSLER ${ }^{\mathrm{b}}-$ Georg KINDERMANN $^{\mathrm{c}}-$ \\ Diana RECHID ${ }^{\mathrm{b}}-$ Kevin SIECK $^{\mathrm{b}}-$ Daniela JACOB $^{\mathrm{b}}$ \\ ${ }^{a}$ Institute of Environment and Earth Sciences, University of West Hungary, Sopron, Hungary \\ ${ }^{\mathrm{b}}$ Climate Service Center, Germany - eine Einrichtung am Helmholtz-Zentrum Geesthacht \\ ${ }^{\mathrm{c}}$ IIASA, International Institute for Applied Systems Analysis Austria
}

\begin{abstract}
A regional-scale case study has been carried out to assess the possible climatic benefits of forest cover increase in Europe. For the end of the 21st century (2071-2090) it has been investigated, whether the projected climate change could be reduced assuming potential afforestation of the continent. The magnitude of the biogeophysical effects of enhanced forest cover on temperature and precipitation means and extremes have been analyzed relative to the magnitude of the climate change signal applying the regional climate model REMO. The simulation results indicate that in the largest part of the temperate zone potential afforestation may reduce the projected climate change through cooler and moister conditions, thus could contribute to the mitigation of the projected climate change for the entire summer period. The largest relative effect of forest cover increase can be expected in northern Germany, Poland and Ukraine. Here, the projected precipitation decrease could be fully compensated, the temperature increase could be relieved by up to $0.5{ }^{\circ} \mathrm{C}$, and the probability of extremely warm and dry days could be reduced. Results can help to identify the areas, where forest cover increase could be the most effective from climatic point of view. Thus they can build an important basis of the future adaptation strategies and forest policy.
\end{abstract}

afforestation / biogeophysical feedbacks / climatic extremes / climate change mitigation

Kivonat-Esettanulmány az erdők klímavédelmi szerepének vizsgálatára Európában. Az esettanulmány célja az erdőterület növekedés éghajlati hatásainak, a klímaváltozás mérsékelésében betöltött szerepének számszerüsítése Európában. A REMO regionális klímamodell segítségével vizsgáltuk, hogy a feltételezett potenciális erdőtelepítéssel milyen irányban és mértékben befolyásolhatók a 2071-2090-es időszakra előrevetített hőmérséklet- és csapadéktendenciák. A modellszimulációk eredményei alapján, potenciális erdőtelepítés feltételezésével nyáron a mérsékelt övi területek döntő része hüvösebb, csapadékosabb lehet. A legnagyobb hatás Németország és Lengyelország északi részén, valamint az ukrán-belorusz-orosz határvidéken várható. Ezeken a területeken az erdőtelepítés hatása a hőmérsékletre egy nagyságrenddel kisebb, mint az üvegházgáz koncentráció változásáé. A klímaváltozással járó csapadékmennyiség-csökkenés azonban szinte teljes egészében kiegyenlíthető lenne, és a szélsőségesen meleg és száraz napok gyakorisága csökkenhet. Az erdő-klíma kölcsönhatások számszerüsítése nem csak az erdők klímavédelmi szerepéről ad információt, hanem az éghajlatváltozás következményeinek megelőzését, enyhítését célzó stratégiák alapja is lehet.

erdőtelepítés / felszín-légkör kölcsönhatás / klímaváltozás mérsékelő hatás / időjárási szélsőségek

\footnotetext{
*Corresponding author: bgalos@emk.nyme.hu; H-9400 SOPRON, Bajcsy Zs. u. 4.
} 


\section{INTRODUCTION}

Human activity influences climate through changes of the chemical composition of the atmosphere as well as through land cover and land use change. Climate conditions in the $21 \mathrm{st}$ century driven by emission change and its impacts on different spatial and temporal scales and sectors have been addressed by several national and international research projects in the last decade (Christensen et al. 2007, Jacob et al. 2008, van den Linden - Mitchell 2009). Regional climate projections for Europe agree in a robust warming tendency in all seasons towards the end of this century. The largest temperature increase is expected in the Mediterranean region, Southern France and over the Iberian Peninsula (Christensen Christensen 2007). Here, the probability of extreme high temperatures, heat waves can also increase compared to the present day conditions (Beniston et al. 2007, Vidale et al. 2007, Beniston 2009, Fischer et al. 2010). The spatial patterns of the precipitation changes show an increase in northern Europe (especially in winter) and decrease in the southern regions (especially in the Mediterranean area in summer; Christensen - Christensen 2007). The Mediterranean and the South-East European regions are the most prone to higher risks of prolonged dry spells by 2100 (Beniston et al. 2007, Bartholy et al. 2007, Mishra - Singh 2010). Whereas in Northern to North-Eastern Europe the number of days with intense precipitation is very likely to increase, which can result in a rise in flood frequencies (Pal et al. 2004, Beniston et al. 2007, Buonomo et al. 2007). Changes of the climatic means and extremes already show impacts on the key sectors such as hydrological systems, infrastructure, human health, agriculture and forestry, which are expected to be more severe under future climate conditions.

Climate change can induce a shift of the spatial distribution of the major ecosystem types. For forests, this phenomenon occurs not only in the boreal zone (through the northern shift of the taiga-tundra limit) but also on the lower limit of the forest distribution (Berki et al. 2009, Mátyás et al. 2010, Czúcz et al. 2011, Führer et al. 2011). Here, ecological models of forest distribution expect growth decline and mass mortality of many zonal tree species whose distributions are limited primarily by recurrent droughts (Mátyás et al. 2010, Czúcz et al. 2011, Bredemeier 2011, Rasztovits et al. 2012). Land cover is also influenced by land management and land use policy. Land cover and land use and their changes are important drivers of weather and climate (Pielke et al. 1998, Drüszler et al. 2010), they can have a determining role in climate regulation. They affect the physical properties of the surface (biogeophysical processes and feedbacks) that control the water and energy exchange between land and atmosphere. Through chemical reactions (biogeochemical processes and feedbacks) they influence the terrestrial carbon exchange and the fluxes of other trace gases and aerosols (Pielke et al. 1998, Feddema et al. 2005, Pitman 2003). There are climate forcings that have basically a warming (e.g. greenhouse gases) or cooling effect (e.g. sulphate aerosols; Pielke et al. 2011). In contrast to them the sign of the temperature response to land cover and land use change are determined by various contrasting feedbacks. They can also depend on the type of the change as well as on the climatic, soil and vegetation characteristics of a region and the length of the analyzed time scale (Sánchez et al. 2007, Anav et al. 2010, Teuling et al. 2010, Wramneby et al. 2010).

Historical land cover and land use changes and their observed impacts on local and regional climate have been documented or reviewed by several studies for different countries (e.g. Feddema et al. 2005, Pielke et al. 2011, Pongratz et al. 2011). One of the major conclusions was that on regional scale, climate response of land cover and land use change has similar magnitude but opposite sign compared to the impact of elevated greenhouse gases and resulting changes of sea surface temperature and sea ice extent (de Noblet-Ducoudre et al. 2012). 
For future time periods, changes of the land cover and land use can lead to the enhancement or reduction of the projected climate change signals expected from increased atmospheric greenhouse gas concentration (Feddema et al. 2005, Bonan 2008, Wramneby et al. 2010). Therefore understanding and assessment of their feedbacks on climate are essential for the adaptation and mitigation strategies.

Europe (with Russia) is the only continent with a significant increase of forest cover in recent times. In the last two decades the annual area of natural forestation and forest planting amounted to an average of 0.78 million hectares/year (FAO 2011). The climatic influence of these land cover changes is still poorly understood. The role of temperate forests in the climate change mitigation is considered smaller or uncertain compared to boreal and tropical forests (Bala et al. 2007, Bonan 2008, Jackson et al. 2008). Model results show contradictory results regarding to their net climate forcing and benefit (e.g. Anav et al. 2010, Gálos et al. 2011a,b).

One of the scientific goals of the EC-FP7 project CC-TAME (Climate Change Terrestrial Adaptation and Mitigation in Europe) was to prepare fine-scale studies for the assessment of the climate protecting effects of land cover and land use change (e.g. Gálos Jacob 2012). In order to contribute to this aim we prepared a regional scale case study to assess

- the biogeophysical effects of a potential afforestation in summer, for the end of the 21 st century and its regional differences within Europe,

- the magnitude of the biogeophysical feedbacks of forest cover increase compared to the projected climate change signal with special focus on the probability and severity of temperature and precipitation extremes.

\section{MODEL AND METHODS}

\subsection{The regional climate model REMO}

The climate change driven by emission change and land cover change have been studied applying the REgional climate MOdel, REMO (Jacob et al. 2001, Jacob et al. 2007). This is a regional three-dimensional numerical model of the atmosphere. The prognostic variables are calculated based on the hydrostatic approximation. Land cover is described by its physical properties in REMO: leaf area index and fractional vegetation cover for the growing and dormancy season, background albedo, surface roughness length of the vegetation, forest ratio, plant-available soil water holding capacity and volumetric wilting point. These properties are allocated in the global dataset of land surface parameters (Hagemann et al. 1999, Hagemann 2002) for each land cover type. Vegetation phenology is represented by the mean climatology of the annual cycle of leaf area index, vegetation ratio and background albedo (Rechid and Jacob 2006, Rechid et al. 2008a,b). The values of these vegetation characteristics are varying monthly throughout the year, the other land surface parameters remain constant in time. In the current model version biogeochemical processes and vegetation dynamics are not considered. For Europe, REMO has been validated against observations and the simulation results have been compared to an ensemble of regional climate model projections (Déqué et al. 2005).

\subsection{Experimental setup}

The simulations have been carried out for Europe (Figure 1), with $0.22^{\circ}$ horizontal grid resolution. REMO was driven with lateral boundary conditions from the coupled atmosphereocean GCM ECHAM5/MPI-OM (Roeckner et al. 2006, Jungclaus et al. 2006). 


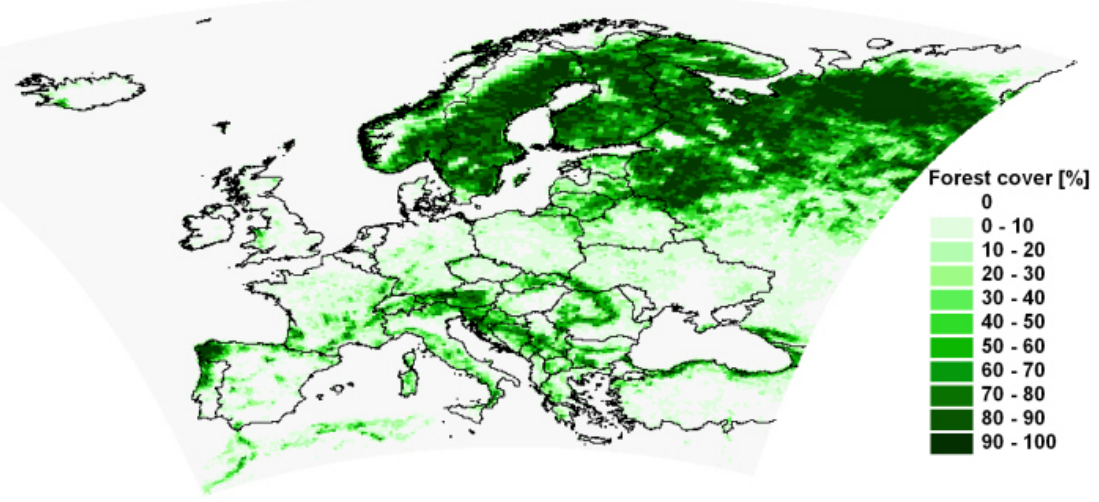

Figure 1. Simulation domain with the present (unchanged) forest cover in the model. Horizontal resolution: $0.22^{\circ}$

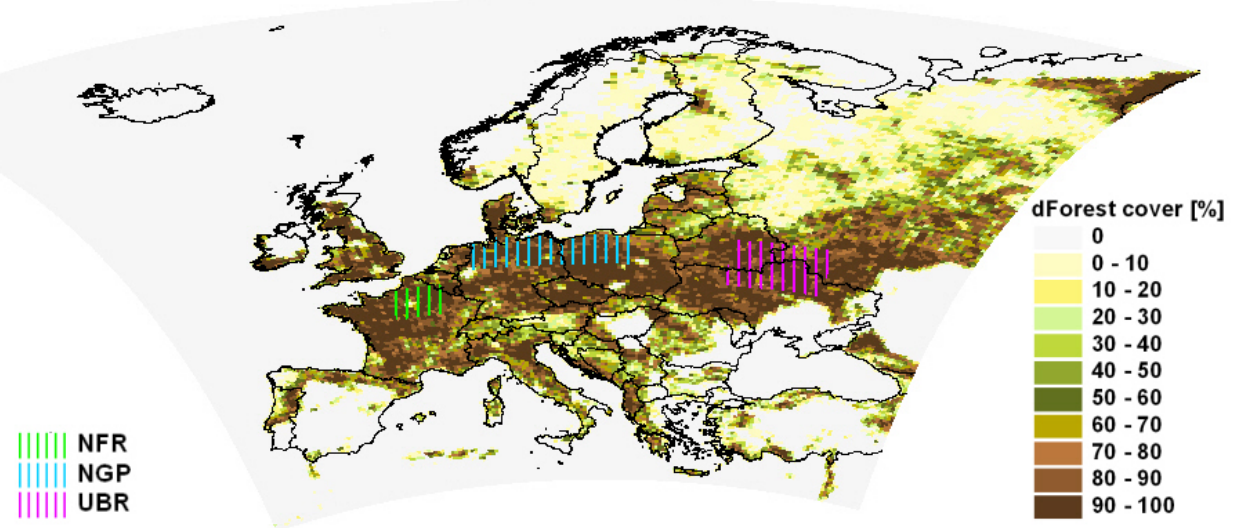

Figure 2. Increase of the forest cover in the potential afforestation simulation compared to the present (unchanged) forested area in the model. The three sub-regions are marked (NFR: Northern France; NGP: Northern Germany and Poland;

UBR: border region of Ukraine, Belarus and Russia)

The following experiments have been performed and analysed (Table 1):

- Reference simulation for the past (1971-1990) with present (unchanged) forest cover.

- Emission scenario simulations for the future (2071-2090) with unchanged forest cover applying the A2 IPCC-SRES emission scenario (continuously increasing global population and regionally oriented economic growth that is more fragmented and slower than in other storylines; Nakicenovic et al. 2000). This served as reference simulation for the land cover change experiments.

Emission scenario simulation with potential afforestation for 2071-2090. The potential afforestation map (Figure 2) is based on the net primary production map for Europe derived from remotely sensed MODIS (Moderate-Resolution Imaging Spectroradiometer) products, precipitation and temperature conditions from the Wordclim database and soil conditions from the International Institute for Applied Systems Analysis. In our study additional forested areas were assumed to be deciduous, because for the end of the 21 st century, projected climate conditions will not be sufficient for larger continuous coniferous forest blocks in the temperate and Mediterranean regions.

The new potential forest cover map has been included into REMO by modification of all characteristic land surface parameters (i.e. leaf area index and fractional vegetation 
cover for the growing and dormancy season, background albedo, surface roughness length due to vegetation, forest ratio, plant-available soil water holding capacity and volumetric wilting point).

Table 1. Analyzed data and time periods (CC-GHG: climate change driven by change of the greenhouse gas concentration, CC-FOR: climate change driven by potential afforestation CC-GHG+FOR: climate change driven by change of the greenhouse gas concentration and potential afforestation)

\begin{tabular}{|c|c|c|c|}
\hline Experiment & Reference simulation & \multicolumn{2}{|c|}{ Emission scenario simulation } \\
\hline Time period & $1971-1990$ & \multicolumn{2}{|c|}{$2071-2090$} \\
\hline $\begin{array}{c}\text { Greenhouse gas } \\
\text { forcing }\end{array}$ & \multicolumn{2}{|c|}{ IPCC-SRES emission scenario A2 } \\
\hline $\begin{array}{c}\text { Land cover } \\
\text { characteristics }\end{array}$ & $\begin{array}{c}\text { Present forest cover } \\
\text { unchanged }\end{array}$ & $\begin{array}{c}\text { Present forest cover } \\
\text { unchanged }\end{array}$ & $\begin{array}{c}\text { Deciduous forests cover } \\
\text { all additional vegetated } \\
\text { area }\end{array}$ \\
\hline & \\
\hline
\end{tabular}

\subsection{Method of analyses}

The analyses of the simulation results focused on the summer months (June, July, August), because of the high radiation input, intense heat and mass exchange.

Climate change driven by change of the greenhouse gas (GHG) concentration (CC-GHG; Table 1) has been investigated comparing the summer precipitation sums and $2 \mathrm{~m}$-temperature means for the period 2071-2090 (without any land cover changes) to 1971-1990. Climate change driven by potential afforestation (CC-FOR; Table 1) has been analyzed comparing the simulation results with- and without forest cover increase for the future time period (2071-2090). Climate change driven by change of the greenhouse gas concentration and potential afforestation (CC-GHG+FOR; Table 1) has been assessed comparing the results of the potential afforestation experiment (2071-2090) to the reference study in the past (1971-1990). The sign and the magnitude of climatic effects of potential afforestation have been analyzed relative to the climate change signal, and the regional differences have been determined within Europe.

Three sub-regions have been selected, where a large forest cover increase has been assumed in the case study and based on the simulation results forests can play a major role in altering the climate change signal. Here, biogeophysical effects of potential afforestation on temperature and precipitation means and extremes have been analyzed more in detail. The sub-regions are the following: Northern France (NFR), Northern Germany and Poland (NGP) and the border region of Ukraine, Belarus and Russia (UBR; Figure 2).

\section{RESULTS}

\subsection{Effects of change of the greenhouse gas concentration and potential afforestation on the summer temperature mean}

First, change of the summer temperature without any forest cover change has been analyzed for the end of the 21st century (2071-2090) with reference to the 20-year period in the 20th century (1971-1990). Corresponding to the results of other regional climate simulations for 
Europe, REMO projects a significant increase of the summer temperature mean, which is expected to be the largest in the southern part of the continent and in the north-eastern areas of the simulation domain (Figure $3 a$ ). In the case of potential afforestation, the higher leaf area index and roughness lengths of forests support the enhanced ability of evapotranspiration (as long as there is enough moisture available in the soil), which leads to cooler conditions in most parts of the temperate zone. In the northern part of Central Europe and in North Ukraine, summer temperature mean can be $0.5^{\circ} \mathrm{C}$ lower compared to the reference simulation (Figure $3 b$ ). Portugal, the Mediterranean coasts and the southern part of the boreal zone show a shift into the warmer direction. For the Mediterranean region a possible reason for it can be that in this dry area vegetation has deeper roots in the reference simulation than forests in the potential afforestation experiment. It means in the model that less water is available for cooling through evapotranspiration.

Figure $3 c$ represents the combined effect of the GHG concentration change and potential afforestation on the summer temperature mean. In the temperate zone afforestation can reduce the projected warming. However, the temperature change signal for potential afforestation is smaller than for GHG concentration change in the whole continent (Figure 3c) thus cannot offset the robust warming. Increase of the forest cover may enhance the climate change signal in the boreal and in the Mediterranean regions but its magnitude is relatively small compared to the effect of the GHG concentration changes.

\subsection{Effects of change of the greenhouse gas concentration and potential afforestation on the summer precipitation sum}

For the end of the 21st century, an increase of temperature is projected to occur with a decrease of precipitation in South and Central Europe and in the southern part of Scandinavia, whereas Northeast Europe can be characterized by warmer and wetter conditions (Figure 4a). Assuming potential afforestation, higher amount of summer precipitation is expected in the largest part of the temperate zone, especially in the northern areas. Here, precipitation increase can reach 50-75 $\mathrm{mm}$ in summer mean (Figure $4 \mathrm{~b}$ ). Enhanced forested area resulted in less precipitation in the northern part of Scandinavia and Russia as well as in smaller areas in Spain and in Central and Southeast Europe (Figure 4b). In contrast with temperature, precipitation change cannot be directly correlated with the local forest cover change, because its formation is influenced also by large-scale circulation.

Increase of forest cover can amplify the projected precipitation change in Sweden, Belarus and Southwest Russia (Figure 4c). Whereas in the northern part of central Europe, Ukraine and eastern Finland the precipitation change driven by GHG concentration change has the opposite sign than due to potential afforestation (Figures 4a-b). Thus depending on their magnitude, afforestation can reduce or fully compensate the effects of the GHG concentration change. Figure $4 c$ shows the areas, where precipitation change driven by afforestation is the same or even larger in magnitude than the climate change signal.

Summing up the results for summer in the period 2071-2090, the cooling and moistening effects of potential afforestation are dominant in most parts of the temperate zone. For temperature, approximately $15-20 \%$ of the climate change signal can be relieved by forest cover increase. Whereas for precipitation, climatic effects of potential afforestation and GHG concentration change have the same order of magnitude but opposite sign. The south-western part of Europe is the most affected by warming and drying driven by GHG concentration change. Here, climatic benefits of forests are simulated to be weaker. 
(a)

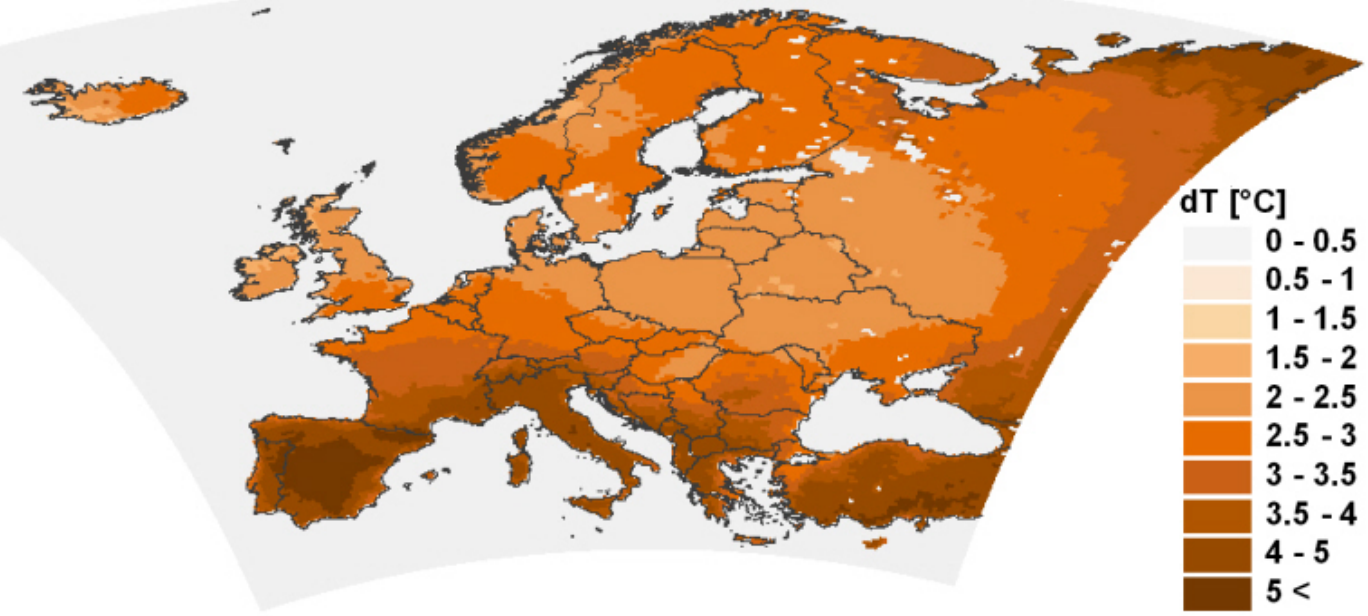

(b)

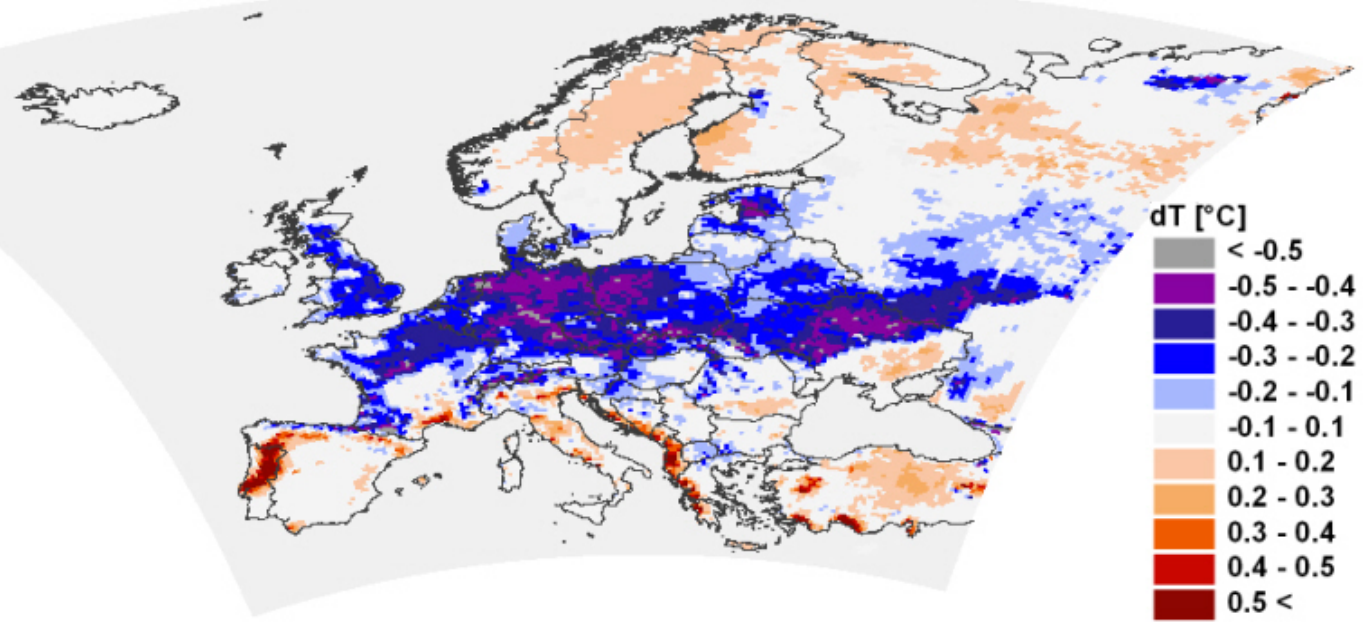

(c)

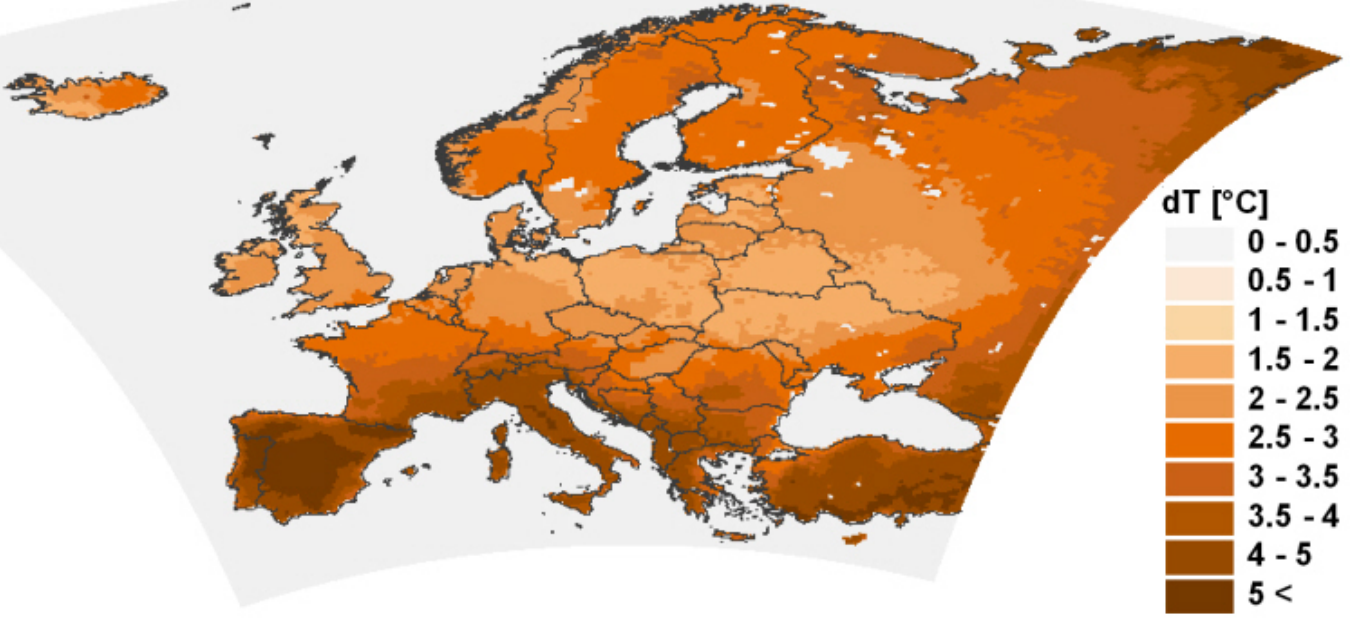

Figure 3. Change of mean summer temperature (dT) driven by (a) change of the $G H G$ concentration (2071-2090 vs. 1971-1990) (b) potential afforestation (2071-2090) and (c) GHG concentration change + potential afforestation (2071-2090 vs. 1971-1990). 
(a)

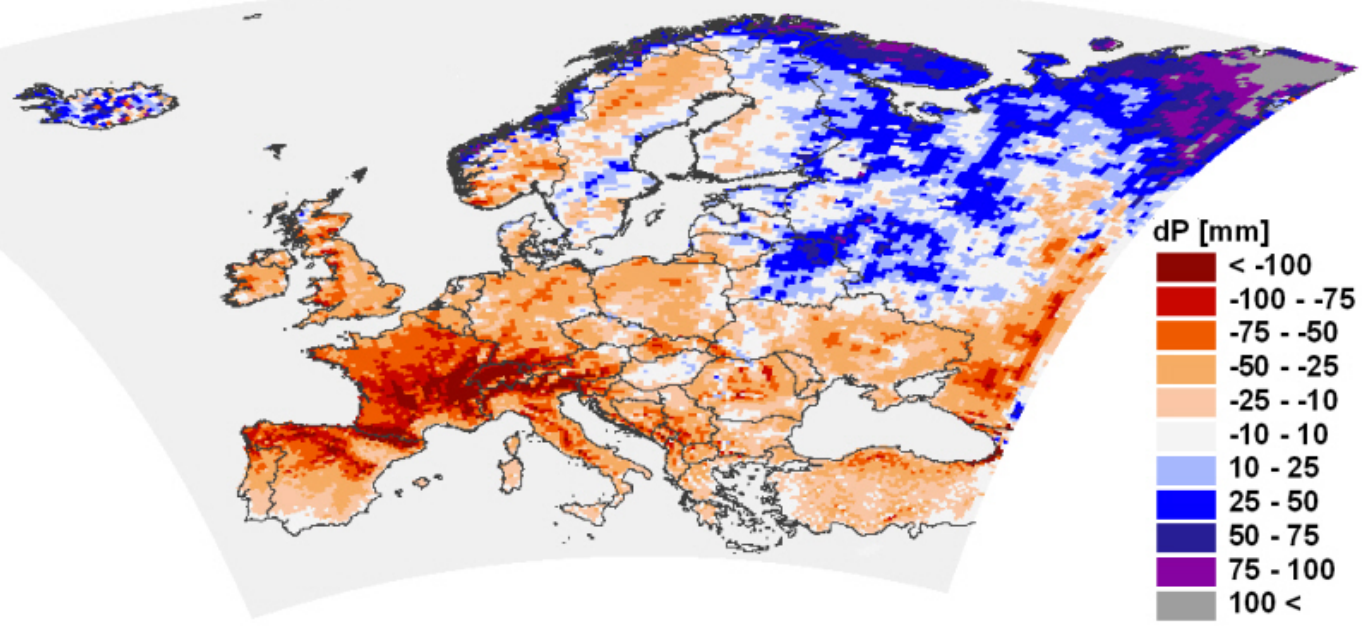

(b)

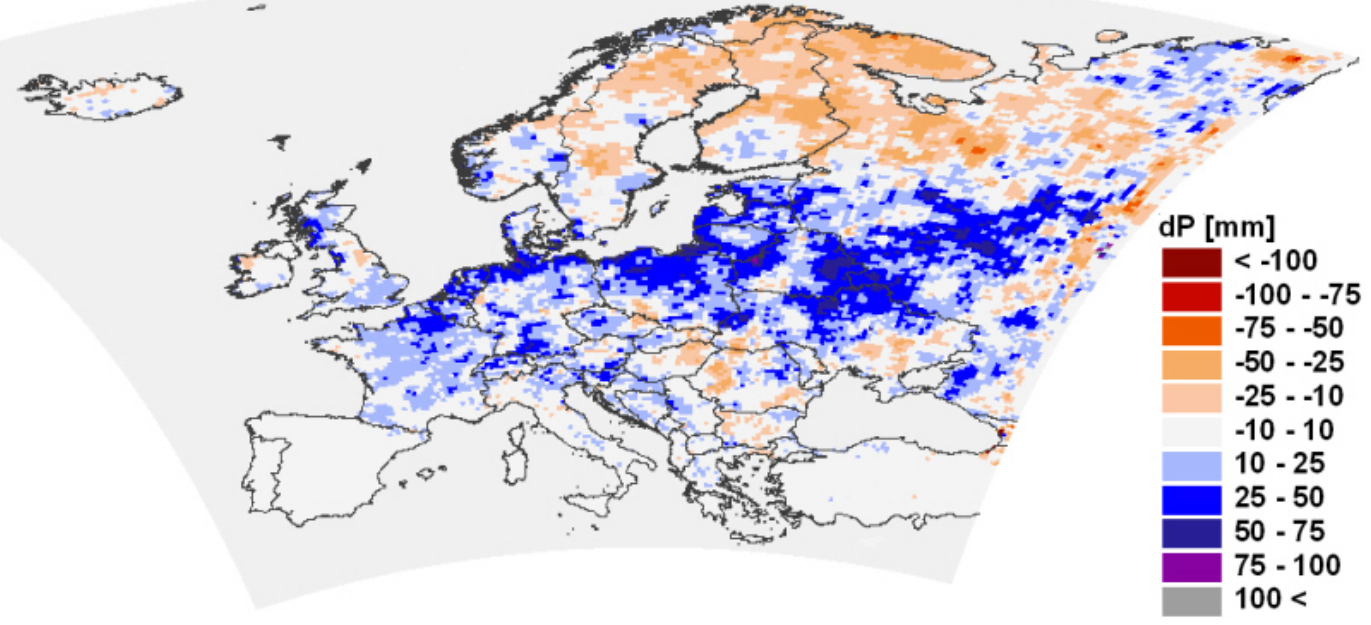

(c)

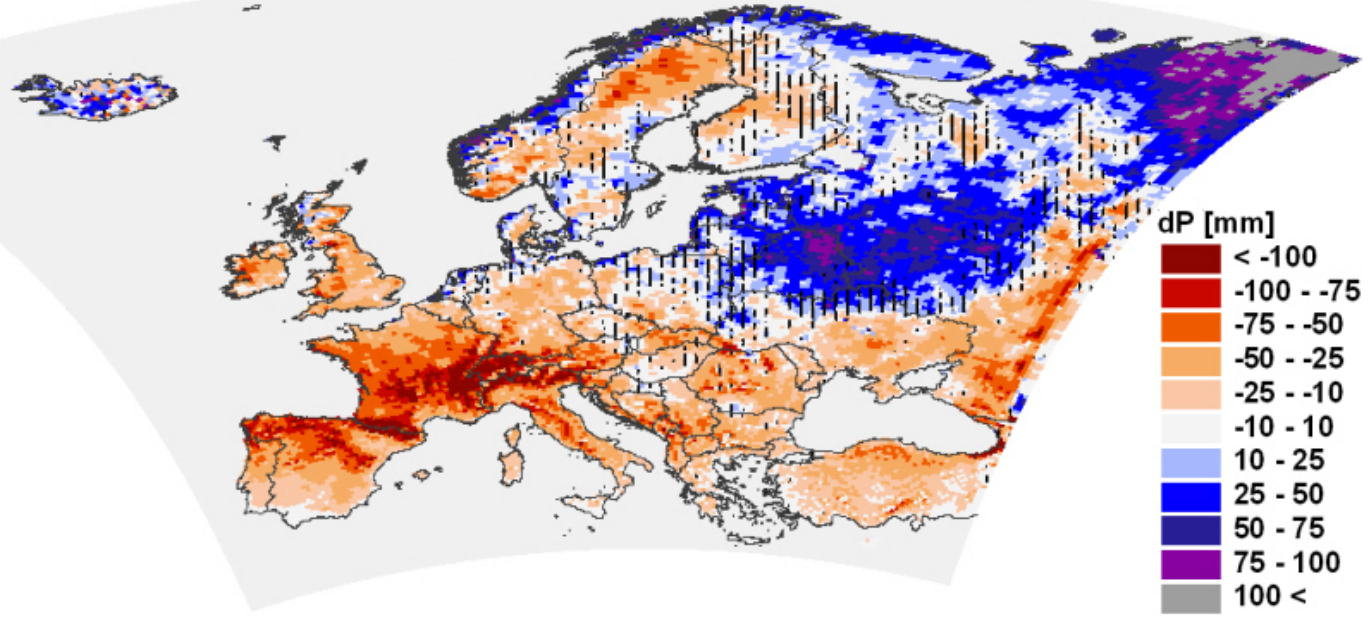

Figure 4. Change of summer precipitation sum (dP) driven by (a) change of the GHG concentration (2071-2090 vs. 1971-1990) (b) potential afforestation (2071-2090) and (c) GHG concentration change + potential afforestation (2071-2090 vs. 1971-1990). The regions are marked, where precipitation change driven by afforestation is the same or larger in magnitude than the climate change signal (only effects over land are shown) 


\subsection{Sign and magnitude of the climate change altering effects of forest cover increase in selected regions}

\subsubsection{Temperature and precipitation means}

In Sect. 3.2 it has been shown that in the northern part of central Europe and Ukraine forests can play a major role in altering the climate change signal. Three sub-regions have been selected within these areas to analyse the temperature and precipitation conditions more in detail (NFR: Northern France, NGP: Northern Germany and Poland, UBR: the border region of Ukraine, Belarus and Russia; Figure 2).

Figure $4 a-b$ shows that for both investigated climatic variables the effects of GHG concentration change can be reduced by the forest cover increase. The temperature change signals for potential afforestation $\left(-0.3--0.4{ }^{\circ} \mathrm{C}\right)$ are weaker than for GHG concentration change $\left(+2.1-+2.4{ }^{\circ} \mathrm{C}\right.$; Figure 5). In smaller areas, climate change mitigating effect of potential afforestation can be stronger (Gálos - Jacob, 2012). Based on the A2 emission scenario, $28 \%$ precipitation decrease $(-66 \mathrm{~mm})$ is expected in the Northern French area. One third of this amount $(22 \mathrm{~mm})$ could be reduced by forest cover increase. In the region of Northern Germany and Poland, the projected drying is smaller $(-13 \% ;-35 \mathrm{~mm})$. If GHG concentration change occurred together with potential afforestation, $80 \%$ of the original climate change signal could be relieved (Figure 5). In the Ukrainian border region, increase of summer precipitation sum driven by potential afforestation $(+14 \% ;+34 \mathrm{~mm})$ can exceed the very small drying of the area due to the enhanced GHG concentration (Figure 5). Thus afforestation would fully compensate the projected climate change signal, as long as there is enough soil moisture available. The combined effect of forest cover and GHG concentration changes for 2071-2090 would result in a net precipitation increase compared to the reference simulation for the past (1971-1990) without any land cover change.

For the analyzed variables, the magnitude of impacts of forest cover increase is similar in the tree sub-regions. Consequently, the regional differences in the relative climatic effects of potential afforestation can be explained by the differences in the temperature and precipitation signal driven by GHG concentration change.

\subsubsection{Temperature and precipitation extremes}

Distribution of the daily temperature means are shifted towards the warmer direction under future climate conditions for the NGP region (Figure 6). Figure 6 illustrates that in the potential afforestation case study the value of the 95 th percentile is $0.5^{\circ} \mathrm{C}$ lower than in the emission scenario simulation with unchanged land cover. Consequently, increase of the forest cover may contribute to the decrease of the probability and severity of extreme high temperatures, thereby to the reduction of the projected climate change signal. (The NFR and UBR regions show similar effects; not shown).

In each of the selected regions the probability of summer days (Tmax $>25{ }^{\circ} \mathrm{C}$ ), hot days $\left(\operatorname{Tmax}>30^{\circ} \mathrm{C}\right)$ and extremely hot days (Tmax $>35^{\circ} \mathrm{C}$ ) are projected to increase significantly towards the end of the 21 st century. Changes driven by potential afforestation have the opposite sign but they are relatively small compared to the effect of the GHG concentration changes (not shown).

Under future GHG concentrations the total number of dry days (daily precipitation sum $<1 \mathrm{~mm}$ ) is projected to be significantly larger. In case of potential afforestation around half of this signal could be relieved in the NGP and UBR regions (Table 2). The probability of extremely large daily precipitation amounts (larger than 95th percentile) is simulated to become higher assuming forest cover increase for all of the three regions. In the UBR area, potential afforestation may enhance the effects of GHG concentration change, resulting in almost twice as much severe precipitation events than with unchanged vegetation (Table 2). 

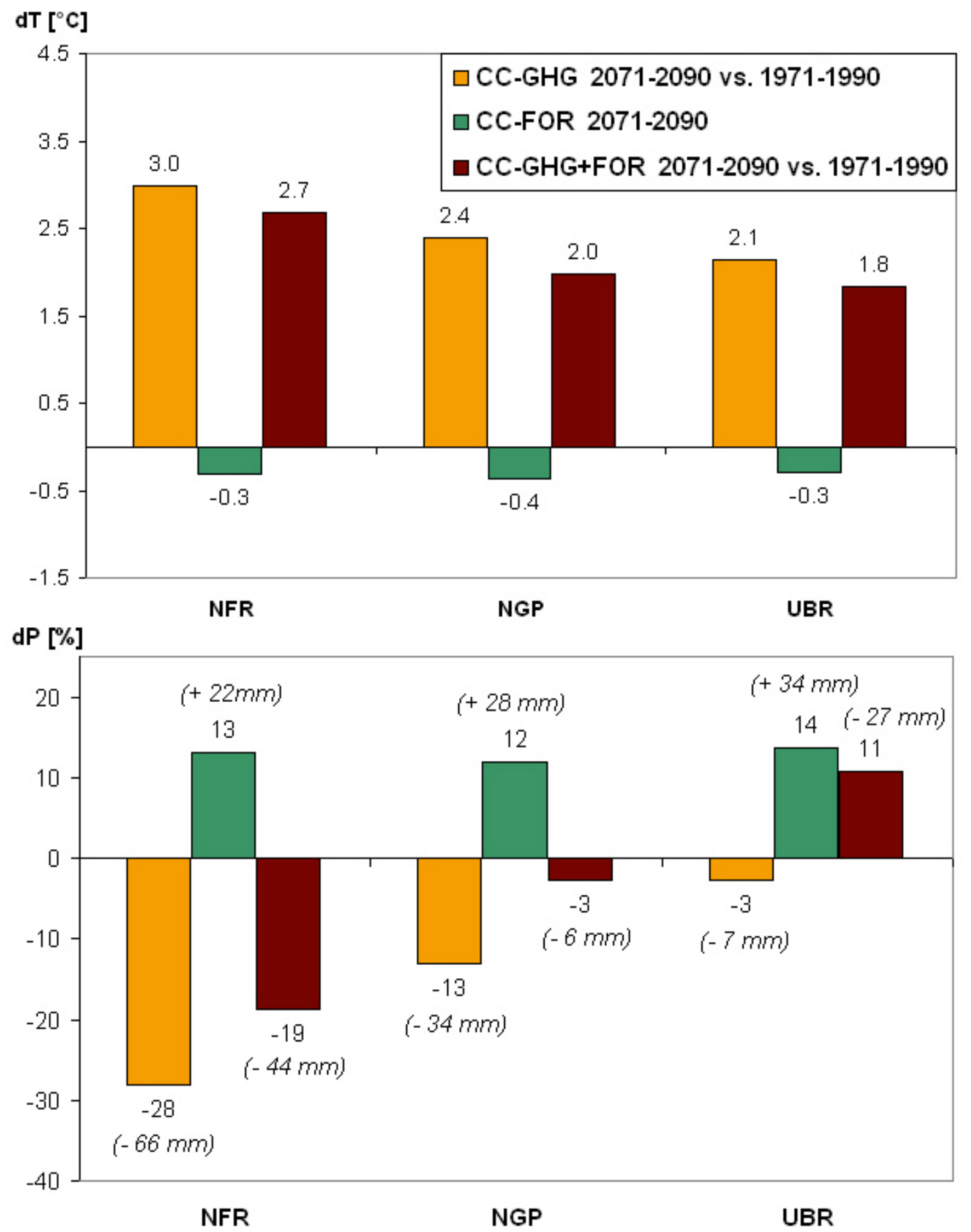

Figure 5. Change of the summer temperature mean (dT; top) and precipitation sum (dP; bottom) driven by change of the GHG concentration (CC-GHG; 2071-2100 vs. 1971-1990), potential afforestation (CC-FOR; 2071-2090) and GHG concentration change + potential afforestation (CC-GHG+FOR; 2071-2090 vs. 1971-1990) in the three investigated regions (NFR: Northern France; NGP: Northern Germany and Poland; UBR: border region of Ukraine, Belarus and Russia) 


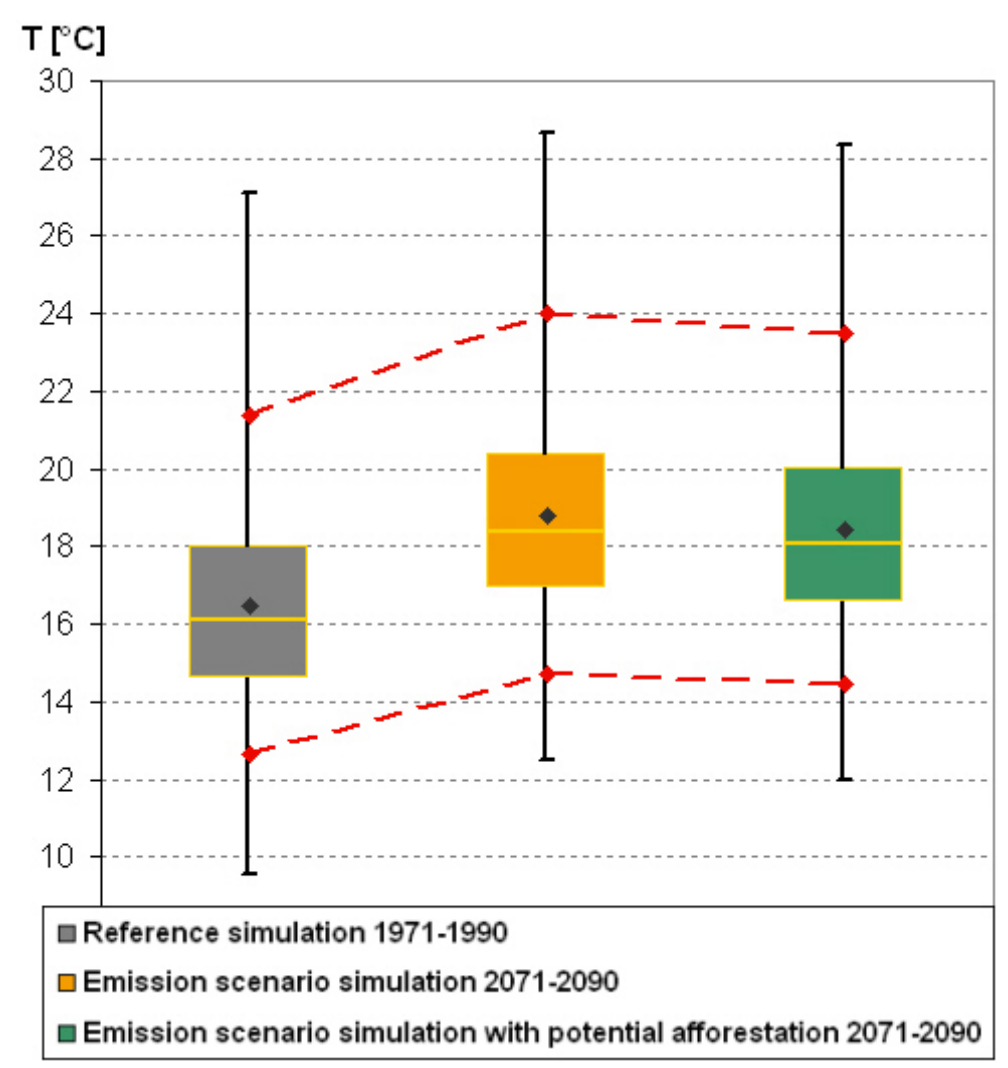

Figure 6. Daily mean temperatures (T) in the summer months within the investigated 20-year time periods for the region Northern Germany and Poland (NGP). The bottom and the top of the boxes are representing the 25th and 75th percentile values. The end of the bars corresponds to the minimum and maximum of the data. The change of the 5th and 95th percentile values driven by GHG concentration change and potential afforestation is visualized by dashed lines

Table 2. Total number of daily precipitation extremes for summer in the investigated 20-year time periods. (CC-GHG: climate change driven by change of the greenhouse gas concentration, CC-FOR: climate change driven by potential afforestation, CC-GHG+FOR: climate change driven by change of the greenhouse gas concentration and potential afforestation; Rday: daily precipitation sum; R95\%: 95th percentile of the daily precipitation in the period 1971-1990; NFR: Northern France; NGP: Northern Germany and Poland; UBR: border region of Ukraine, Belarus and Russia.)

\begin{tabular}{|c|c|c|c|c|c|c|}
\hline \multirow{2}{*}{ Extreme index } & \multirow{2}{*}{$\begin{array}{l}\text { Definition } \\
\text { [unit] }\end{array}$} & \multirow{2}{*}{ Region } & \multirow{2}{*}{$\begin{array}{l}\text { Number of days } \\
(1971-1990)\end{array}$} & \multicolumn{3}{|c|}{ Change of the number of days } \\
\hline & & & & CC-GHG & CC-FOR & CC-GHG+FOR \\
\hline \multirow{3}{*}{$\begin{array}{l}\text { Number of } \\
\text { dry days }\end{array}$} & \multirow{3}{*}{$\begin{array}{c}\text { Rday }<1 \mathrm{~mm} \\
{[\text { day }]}\end{array}$} & NFR & 909 & +234 & -55 & +179 \\
\hline & & NGP & 564 & +178 & -88 & +90 \\
\hline & & UBR & 712 & +73 & -42 & +31 \\
\hline \multirow{3}{*}{$\begin{array}{l}\text { Number of } \\
\text { very wet days }\end{array}$} & \multirow{3}{*}{$\begin{array}{c}\text { Rday }>\text { R95\% } \\
\text { [day] }\end{array}$} & NFR & 47 & -11 & +13 & +2 \\
\hline & & NGP & 64 & -5 & +15 & +10 \\
\hline & & UBR & 57 & +29 & +26 & +55 \\
\hline
\end{tabular}




\section{CONCLUSIONS}

A regional scale case study has been carried out to investigate the role of the forest cover increase in adapting to climate change in Europe. For the end of the 21 st century, simulation results of the regional climate model REMO have been analyzed in order to quantify the magnitude of the climatic effects of afforestation relative to the climatic impacts of GHG concentration change. The regions have been determined, in which forests can play a major role in altering the precipitation and temperature projections for summer. Here, the biogeophysical feedbacks of afforestation on the climatic means and extremes have been investigated more in detail.

Results of the sensitivity study can be summarized as follows:

- In the largest part of the temperate zone potential afforestation may reduce the projected climate change through cooler and moister conditions, thus could contribute to the mitigation of the projected climate change for the entire summer period, as long as there is enough soil moisture available.

- The largest relative effect of forest cover increase can be expected in northern Germany, Poland and Ukraine. Here, for temperature, approximately 15-20\% (up to $0.4-0.5^{\circ} \mathrm{C}$ ) of the climate change signal can be relieved. For precipitation, climatic effects of potential afforestation and GHG concentration change have the same order of magnitude but opposite sign, which means, that projected precipitation decrease could be strongly reduced or fully compensated.

- In each of the analyzed sub-regions the strong increase of the total number of warm extremes can be slightly reduced by potential afforestation. Increase of forest cover would result in more severe heavy precipitation events. The probability of dry days would decrease.

The simulation results indicate that large, continuous forest blocks have robust biogeophysical effects on the regional climate. The magnitude of the climatic effects of afforestation relative to the climatic impact of GHG concentration change shows large spatial differences within Europe. Similarly to the conclusions of a Hungarian case study (Gálos et al. 2011a,b) there are regions, where increase of forest cover can play an important role in reducing the probability and severity of climatic extremes. Thus from a practical point of view, our assessment concerning to the climate change altering effects of forest cover change contributes to the future adaptation strategies in the European agriculture, forestry and water management. Our results also underline that in the mostly climate change affected part of the continent, vegetation feedbacks have weaker influence on the atmospheric circulation in comparison to the greenhouse-gas forcing (Betts 2007, Wramneby et al. 2010) and afforestation is not a substitute for reduced greenhouse-gas emissions (Arora - Montenegro, 2011). On local scale the benefits and ecological services of forest cover are highly valued.

For the introduced sensitivity study, one regional climate model has been applied driven by one emission scenario. The simulated impacts can also depend on the representation of the land surface properties and land cover related processes in the model (Boisier et al. 2012). There are differences among regional climate models in the parameters describing the land surface types and the role of these parameters in the vegetation-climate interactions that determines the sensitivity of the model to land cover changes. As example, in the land cover change experiment of Anav et al. (2010) the simulated total evapotranspiration shows large sensitivity to the modification of the stomatal resistance, which had a significant impact on the final conclusion of their study. In contrast to this, in the feedback-chain of the present study with REMO, the simulated transpiration reacts to the variation of the stomatal resistance, however the sensitivity of the total evapotranspiration is smaller because of the important role of the atmospheric demand. This can give an explanation to the contradictory 
results of Anav et al. (2010) regarding to the impact of afforestation on temperature extremes for the same region. Further difference among regional climate models can be the number of the soil layers. The distribution of water in the soil and the water movement between the layers can also play an important role in the evapotranspiration through the available amount of soil moisture. The current bucket scheme in REMO is under improvement (Hagemann pers. comm.).

Further challenge is the elimination of the model-depending effects and reduction of the related uncertainties. To achieve this, multimodel ensembles of climate model simulations and intercomparison studies are essential, which is the aim of recent EU-projects (e.g. LUCID; de Noblet-Ducoudre et al. 2012). Land cover and land use changes directly affect regional climate. Increase of spatial resolution makes the correct description of land cover and the simulation of land - atmosphere feedbacks even more important. The land cover parameterization and land surface schemes of climate models should be validated and improved based on appropriate observational and satellite database, which is one of the research questions of the on-going EU project FLUXNET.

In our simulations, projected forest cover and forest composition shifts triggered by climate change (i.e. the expected reduction of the forested area and mass mortality in the drought threatened areas; Mátyás et al. 2010, Czúcz et al. 2011) have not been taken into account. There is no information available about the climate change effects on the distribution of forests as well as about the land use change due to land management and policy in Europe beyond limited case studies, so far. Vegetation dynamics and phenology were not considered, however, they can influence the simulated water and energy exchange between vegetation and atmosphere through the temporal change of the vegetation properties (e.g. albedo, leaf area index, surface roughness).

In these analyses we focused on the biogeophysical processes. But it is important to recognize that they can be intensified or dampened by the biogeochemical effects (e.g. carbon sequestration of forests and soil, which is one of the large unknowns under future climate conditions; Barcza et al. 2009, Booth et al. 2012). Higher $\mathrm{CO}_{2}$ concentrations can also lead to the increase of the stomatal resistance thereby to the inhibition of the transpiration, which can amplify the global warming (Cao et al. 2010, Gopalakrishnan et al. 2011). Therefore to draw appropriate conclusions for decision makers about the role of the forests in the climate change mitigation and adaptation, the combined effects should be analyzed.

The accurate representation of land use and land cover change in past, present and future climate simulations is crucial to understand and quantify the interactions and feedbacks with the climate and socio-economic systems, respectively (Hibbard et al 2010, Mahmood et al. 2010, Pielke et al. 2011), as well as the ecosystem services of the land cover types and the role of humans in the climate system. These can be reached only by improved international and interdisciplinary collaboration across modelling, observing and measurement communities.

Acknowledgements: The climate model simulations have been carried out in the Max Planck Institute for Meteorology (MPI-M), Hamburg. The authors give special thanks to Swantje Preuschmann, Claas Teichmann and Christopher Moseley for their scientific contribution to the project that was an important basis of our study. Thanks to the Regional Modelling Group of the MPI-M and to Stefan Hagemann for the fruitful scientific discussions about the simulation results. We thank Prof. Dr. Csaba Mátyás for his expertise and suggestions regarding to the practical importance of this topic. The REMO simulations without land cover change have been carried out in the frame of the EU-project ENSEMBLES. This research was financially supported by the EC-FP7 project CC-TAME (www.cctame.eu; grant agreement $\left.\mathrm{n}^{\circ} 212535\right)$, as well as by the TÁMOP 4.2.2-08/1-2008-0020 and 4.2.2.B-10/1-2010-0018 "Talentum" joint EU-national research projects. 


\section{REFERENCES}

Anav, A. - Ruti, P.M. - Artale, V. - Valentini, R. (2010): Modelling the effects of land-cover changes on surface climate in the Mediterranean region. Clim. Res. 41: 91-104.

ARORA, V.K. - MONTENEGRO, A. (2011): Small temperature benefits provided by realistic afforestation efforts. Nature Geoscience doi: 10.1038/NGEO1182,

Bala, G. - CAldeira, K. - Wickett, M. - Phillips, TJ. - Lobell, D.B. - Delire, C. - Mirin, A. (2007): Combined climate and carbon-cycle effects of large-scale deforestation. Proc Natl Acad Sci USA, 104: 6550-6555.

BARCZA, Z. - HASZPRA, L. - SOMOgYi, Z. - Hidy, D. - Lovas, K. - ChurkinA, G. - Horváth L. (2009): Estimation of the biospheric carbon dioxide balance of Hungary using the BIOME-BGC model. Időjárás 113(3): 203-209.

BARTHOLY, J. - PONGRÁCZ, R. - GELYBÓ, GY. (2007): Regional climate change expected in Hungary for 2071-2100. Applied Ecology and Environmental Research 5: 1-17.

Beniston, M. - Stephenson, D.B. - Christensen, O.B. - Ferro, C.A.T. - Frei, C. - Goyette, S. Halsnaes, K. - Holt, T. - Jylhä, K. - Koffi, B. - Palutikof, J. - SchÖll, R. - Semmler, T. WoTH, K. (2007): Future extreme events in European climate: an exploration of regional climate model projections. Clim Change 81:71-95.

BENISTON, M. (2009): Trends in joint quantiles of temperature and precipitation in Europe since 1901 and projected for 2100. Geophys Res Lett 2009, 36:L07707. doi:10.1029/2008GL037119

Berki, I. - RASZTOVITS, E. - MóRICZ, N. - MÁTYÁS, CS. (2009): Determination of the drought tolerance limit of beech forests and forecasting their future distribution in Hungary. Cereal Research Communations 37: 613-616.

BETTS, R. (2007): Implications of land ecosystem-atmosphere interactions for strategies for climate change adaptation and mitigation. Tellus 59B: 602-615.

Boisier, J.P. - DE Noblet-DuCoudré, N. - PitMAn, A.J. - CRuz, F.T. - DeliRe, C. -VAN DEN HURK, B.J.J.M. - VAN DER MOLEN, M.K. - MÜlleR, C. - VOldOIRE, A. (2012): Attributing the impacts of land-cover changes in temperate regions on surface temperature and heat fluxes to specific causes: Results from the first LUCID set of simulations. J. Geophys. Res. 117: D12116, doi:10.1029/2011JD017106.

Booth, B.B.B. - Chris, D.J. - Collins, M. - TotTerdell, I.J. - CoX, P.M - Sitch, S. HunTINGFORD, C. - BETTS, R.A.- HARRIS, G.R. - LlOYD, J. (2012): High sensitivity of future global warming to land carbon cycle processes. Environ. Res. Lett. 7024002 (8pp) doi: $10.1088 / 1748-9326 / 7 / 2 / 024002$

BONAN, G.B. (2008): Forests and climate change: forcings, feedbacks, and the climate benefits of forests. Science 320: 1444-1449.

BREDEMEIER, M. (2011): Forest, climate and water issues in Europe. Ecohydrol 4:159-167.

BuONOMO, E. - JONES, R. - HUNTINGFORD, C. - HANNAFORD, J. (2007): On the robustness of changes in extreme precipitation over Europe from two high-resolution climate change simulations. Q J R Meteor Soc, 133:65-81.

CAO, L, - BALA, G. - CALDEIRA, K. - NEMANI, R. - BAN-WEISSA, G. (2010): Importance of carbon dioxide physiological forcing to future climate change. Proc. Natl. Acad. Sci. 107(21):9513-1918

Christensen, J.H. - CARTER, T.R. - RuMMUKAinen, M. - AMANATIDIS, G. (2007): Evaluating the performance and utility of regional climate models: the PRUDENCE project. Clim. Change 81: 1-6. doi:10.1007/s10584-006-9211-6

Christensen, J.H. - Christensen, O.B. (2007): A summary of the PRUDENCE model projections of changes in European climate by the end of this century. Clim. Change 81:7-30.

CZÚCZ, B. - GÁLHIDY, L. - MÁTYÁS, Cs. (2011): Present and forecasted xeric climatic limits of beech and sessile oak distribution at low altitudes in Central Europe. Ann. For. Sci. 68 (1): 99-108.

DÉQué, M. - Jones, R.G. - WiLD, M. - Giorgi, F. - Christensen, J.H. - HASSELl, D.C. - VIDALE, P.L. RoCKEL, B. - JACOB, D. - KJELlströM, E. - DE CASTRO, M. - KuCHARSKi, F. VAN DEN HURK ,B. (2005): Global high resolution versus Limited Area Model scenarios over Europe: results from the PRUDENCE project. Climate Dynamics 25: 653-670. 
DRÜSZLER, Á. - CSIRMAZ, K. - VIG, P. - MIKA, J. (2010): Effects of documented land use changes on temperature and humidity regime in Hungary. In: Saikia, S.P. (ed.): Climate Change. Dehradun: International Book Distributors. ISBN: 81-7089-370-4, 394-418.

FAO (2011): The State of the World's Forests 2011 Food and Agriculture Organisation of the United Nations; Rome

Feddema, J.J. - Oleson, K.W. - Bonan, G.B. - Mearns, L.O. - Buja, L.E. - Meehl, G.A. WASHINGTON, W.M. (2005): The Importance of Land-Cover Change in Simulating Future Climates. Science 310: $1674-1678$.

FISCHER, E.M. - SCHÄR, C. (2010): Consistent geographical patterns of changes in high-impact European heatwaves. Nature Geoscience 2010, 3:398-403.

FÜHRER, E. - MAROSI, GY. - JAGODICS, A. - JUHÁSZ, I. (2011): A possible effect of climate change in forest management (in Hungarian). Erdészettudományi Közlemények 1(1): 17-28.

GÁlOS, B. - MÁTYÁS, CS. - JACOB, D. (2011a): Regional characteristics of climate change altering effects of afforestation. Environ. Res. Lett. 6044010 (9pp) doi:10.1088/1748-9326/6/4/044010

GÁLOS, B. - JACOB, D. - MÁTYÁS, Cs. (2011b): Effects of simulated forest cover change on projected climate change - a case study of Hungary. Acta Silv. Lign. Hung. 7: 49-62.

GÁLOS, B. - JACOB, D. (2012): Regional-scale assessment of the climatic role of forests under future climate conditions. In: Liu, G. (ed). Greenhouse Gases - Emission, Measurement and Management. ISBN 979-953-307-224-0, 295-314.

GOPALAKRISHNAN, R. - BALA, G. - JAYARAMAN, M. - CAO, L. - NEMANI, R.N.H. - RAVINDRANATH, N.H. (2011): Sensitivity of terrestrial water and energy budgets to CO2-physiological forcing: an investigation using an offline land model. Environ. Res. Lett. 6044013 (7pp). doi:10.1088/17489326/6/4/044013

HagemanN, S. (2002): An improved land surface parameter dataset for global and regional climate models. Report 336, Max-Planck-Institute for Meteorology, Hamburg

Hagemann, S. - Botzet, M. - DÜMENIL, L. - MACHENhaUER, M. (1999): Derivation of global GCM boundary conditions from $1 \mathrm{~km}$ land use satellite data. Report 289 Max-Planck-Institute for Meteorology, Hamburg

Hibbard, K. - Janetos, A. - Van VuUren, D.P. - Pongratz, J. - Rose, S.K. - BetTs, R. HEROLD, M. - FEDDEMA, J.J. (2010): Research priorities in land use and land cover change for the earth system and integrated assessment modelling. Int J Climatol, 30: 2118-2128.

JACKSON, R.B. - RANDERSON, J.T. - CANADELl, J.G. - ANDERSON, R.G. - AVISSAR, R. BALDOCCHI, D.D. - BONAN, G.B. - CALDEIRA, K. - DiFFENBAUGH, N.S. - Field, C.B. HungATE, B.A. - JoBBÁGY, E.G. - KUEPPERS, L.M. - NoSETtO, M.D. - PATAKI, D.E. (2008): Protecting climate with forests. Environ. Res. Lett. 3044006 (5pp) doi: 10.1088/17489326/3/4/044006

Jacob, D. - Kotova, L. - Lorenz, P. - Moseley, C. - Pfeifer, S. (2008): Regional climate modeling activities in relation to the CLAVIER project. Időjárás 112: 141-153.

JACOB, D. - BÄRRING, L. - Christensen, O.B. - Christensen, J.H. - DE CASTRO, M. - DÉQUÉ, M. Giorgi, F. - HAgEMANN, S. - Hirschi, M. - JONES, R. - KJELlSTRÖM, E. - LENDERINK, G. Rockel, B. - SÁnchez, E. - Schär, C. - Seneviratne, S.I. - Sommot, S. - VAN Ulden, A. VAN DEN HURK, B. (2007): An inter-comparison of regional climate models for Europe: model performance in present-day climate. Climatic Change 81: 31-52.

JACOB, D. - ANDRAE, U. - Elgered, G. - Fortelius, C. - GRAHAM, L.P. - JACKSON, S.D. KARSTENS, U. - KOEPKEN, CHR. - LindAU, R. - PODZUN, R. - ROCKel, B. - RUBEl, F. - SASS, H.B. SMITH, R.N.D - VAN DEN HURK, B.J.J.M. - YANG, X. (2001): A Comprehensive Model Intercomparison Study Investigating the Water Budget during the BALTEX-PIDCAP Period. Meteorology and Atmospheric Physics 77 (1-4): 19-43.

JungClaus, J.H. - KeENLYSide, N. - BotZet, M. - HAAK, H. - LuO, J-J. - LATIF, M. - MAROtZKe, J. MIKOLAJEWICZ, U. - ROECKNER, E. (2006): Ocean circulation and tropical variability in the coupled model ECHAM5/MPI-OM. J. Climate 19: 3952-3972.

VAN DER LINDEN P, MITCHELL J.F.B. (Eds) (2009): ENSEMBLES: Climate Change and its Impacts: Summary of research and results from the ENSEMBLES project., Met Office Hadley Centre, FitzRoy Road, Exeter EX1 3PB, UK; 160 p. 
Mahmood, R. - Pielke, R.A. - SR.Hubbard, K.G. - Niyogi, D. - Bonan, G. - LAwrence. BAKER, B. - MCNIDER, R. - MCAlPINE, C. - ETTER, A. - ET AL. (2010): Impacts of land use land cover change on climate and future research priorities. Bull Am Meteorol Soc, 91:37-46.

MÁTYÁs, Cs. (2009): Ecological perspectives of climate change in Europe's continental, droughtthreatened Southeast. In: Groisman, P.Y. - Ivanov, S.V. (eds.): Regional aspects of climateterrestrial-hydrologic interactions in non-boreal Eastern Europe. NATO Science Series, Springer Verl. 31-42.

MÁtyÁs, Cs. - Berki, I. - CzúCZ, B. - GÁlos, B. - MóRicz, N. - RASZTOvits, E. (2010): Future of beech in Southeast Europe from the perspective of evolutionary ecology. Acta Silv. Lign. Hung. 6: 91-110.

MisHRA, A.K. - SingH, V.P. (2010): A review of drought concepts. J of Hydrology 391:202-216.

NAKICENOVIC N ET AL. (2000): IPCC Special Report on Emission Scenarios. Cambridge: Cambridge University Press, p 599.

DE NoBlet-Ducoudré, N. AND COAuthors (2012): Determining Robust Impacts of Land-UseInduced Land Cover Changes on Surface Climate over North America and Eurasia: Results from the First Set of LUCID Experiments. J. Climate, 25, 3261-3281.

PAL, J.S. - GIORGI, F. - BI, X. (2004): Consistency of recent European summer precipitation trends and extremes with future regional climate projections. Geophys. Res. Lett. 2004, 31 L13202 (4p). doi: 10.1029/2004GL019836

PielKe, R.A. - AVISSAR, SR.R. - RAuPACh, M. - Dolman, A.J. - Zeng, X. - DenNING, A.S. (1998): Interactions between the atmosphere and terrestrial ecosystems: influence on weather and climate. Global Change Biology 4: 461-475.

Pielke, SR. - Roger A. -Pitman, A. -Niyogi, D. - Mahmood, R. - McAlpine, C. - Hossain, F. -

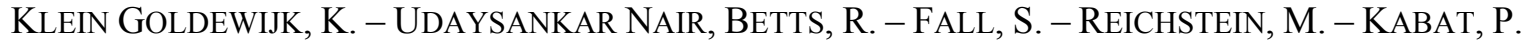
- DE NoBlet, N. (2011): Land use/land cover changes and climate: modelling analysis and observational evidence. WIREs Clim Change 2: 828-850.

PITMAN, A.J. (2003): The evolution off, and revolution in, land surface schemes designed for climate models. Int. J. of Climatol. 23: 479-510.

Pongratz, J. - Reick, C.H. - Raddatz, T. - CAldeira, K. - Claussen, M. (2011): Past land use decisions have increased mitigation potential of reforestation. Geophys Res Lett 38 L15701. doi:10.1029/2007GL031296

Rasztovits, E. - MóRICZ, N. - Berki, I. - Pötzelsberger, E. - MÁtyÁs, Cs. (2012): Evaluating the performance of stochastic distribution models for European beech at low-elevation xeric limits. Időjárás 116(3): 173-194.

RECHID, D. - JACOB, D. (2006): Influence of monthly varying vegetation on the simulated climate in Europe. Meteorol Z. 15: 99-116.

RECHID, D. - RADDATZ, T.J. - JACOB, D. (2008a): Parameterization of snow-free land surface albedo as a function of vegetation phenology based on MODIS data and applied in climate modelling. Theor. Appl. Climatol. 95: 245-255.

REChiD, D. - HAGEMANN, S. - JACOB, D. (2008b): Sensitivity of climate models to seasonal variability of snow-free land surface albedo. Theor. Appl. Climatol. 95: 197-221. doi: 10.1007/s00704-007-0371-8

Roeckner, E. - Brokopf, R. - Esch, M. - Giorgetta, M. - Hagemann, S. - Kornblueh, L. MANZINI, E. - SCHLESE, U. - SCHUlzWEIDA, U. (2006): Sensitivity of simulated climate to horizontal and vertical resolution in the ECHAM5 atmosphere model. J. Clim. 19: 3771-3791.

SÁNCHEZ E, GAERTNER MA, GALLARDO C, PADORNO E, ARRIBAS A, CASTRO M (2007): Impacts of a change in vegetation description on simulated European summer present-day and future climates. Clim Dyn 29: 319-332.

TEULING, A.L. et al. (2010): Contrasting response of European forest and grassland energy exchange to heatwaves. Nature Geoscience 3: 722-727.

VIDALE PL, LÜTHI D, WEGMANN R, SCHÄR C (2007): European summer climate variability in a heterogeneous multi-model ensemble. Climatic Change 81: 209-232.

WramneBY, A. - SMith, B. - SAMUELSSON, P. (2010): Hot spots of vegetation-climate feedbacks under future greenhouse forcing in Europe. J. Geophys. Res. 115: D21119 doi:10.1029/2010JD014307 